\title{
User Experience Based Mobile Application Design for Boat Loaning at Marine Tourism in Indonesia
}

\author{
https://doi.org/10.3991/ijim.v14i04.11227 \\ Fedelis Brian Putra Prakasa, Melky Radja, Suyoto $\left({ }^{(}\right)$ \\ Universitas Atma Jaya Yogyakarta, Yogyakarta, Indonesia \\ suyotodstaff.uajy.ac.id
}

\begin{abstract}
Boat loaning in marine tourism in Indonesia significantly impacts the continuity of tourism activities. It is because some nautical tourism destinations in Indonesia use ships as a means of transportation that cannot be separated from tourism activities. The problem is, there is a lack of information availability; for example, event information, destination, and access for boat loaning. That makes it difficult for tourists to be able to enjoy marine tourism. Therefore, the purpose of this study is to design a prototype of a mobile application that can help overcome the problem of limited information and access to marine tourism transportation, and be able to answer the needs of tourists regarding tourist information using the user experience as a design system. The user experience method will be applied in application design testing, to obtain development aspects in the ship transportation ordering application, according to user needs. The results of this study are the prototype design based on user experience. The final result shows $87.5 \%$ response agree with this prototype design. This study applies the method of boat loaning by utilising cooperation between agents and ship providers to provide Ease of access to information on marine tourism transportation to prospective tourists.
\end{abstract}

Keywords - Marine Tourism, User Experience Design, Boat Loaning.

\section{$1 \quad$ Introduction}

Marine tourism is one of the crucial sectors of tourism. Marine tourism utilises the natural resources of the sea as a tourist attraction. Also, the natural beauty of the coast and supporting recreational activities are the main attraction. In Indonesia, there are several marine tourism locations, which are the regional development priorities which can be seen in table 1 . 
Table 1. Indonesia marine tourism location

\begin{tabular}{|l|}
\hline \multicolumn{1}{|c|}{ Regional development of marine tourism } \\
\hline Kepulauan Seribu, DKI Jakarta \\
\hline Tanjung Kelayang, Bangka Belitung \\
\hline Tanjung Lesung, Banten \\
\hline Mandalika, West Nusa Tenggara \\
\hline Labuan Bajo, East Nusa Tenggara \\
\hline Wakatobi, Southeast Sulawesi \\
\hline Morotai Island, North Maluku \\
\hline
\end{tabular}

In table 1 , it can be seen that the regions are the priority of developing marine tourism. In addition to these locations, there are several locations for marine tourism in Indonesia, especially diving tourism. This location can be seen in Figure 1.

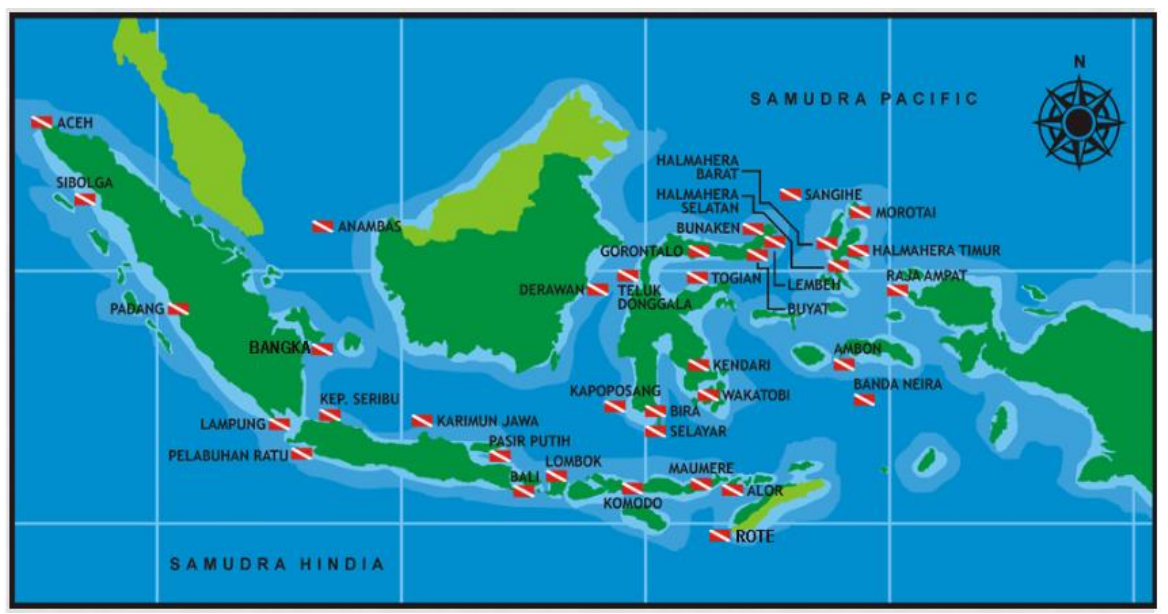

Fig. 1. Diving Map in Indonesia

In figure 1, there are 36 diving spots spread throughout Indonesia. Location data for marine tourism and diving maps, obtained from the report development of marine tourism (in the Indonesian language). Marine tourism is also a type of tourism that can produce many tourists, both local ( 1 million) and foreign (9 million) according to 2014 data [1]. In Indonesia, marine tourism has a development priority of $35 \%$ of all tourism sectors. Marine tourism in Indonesia is divided into three groups, namely coastal tourism as much as $60 \%$, marine $25 \%$, and underwater tourism $15 \%$. Marine tourism is suitable for development in Indonesia. It is because Indonesia is an archipelago that has 17,408 thousand islands based on the sea and fisheries ministry (2013), most of which are small islands. From this tiny archipelago, it is possible to develop maritime tourism, which can undoubtedly increase state revenues [2]. Indonesia began offering various kinds of recreation on its marine tourism. The enjoyment starts from coral reef tourism 
[3], snorkelling [4], surfing [5], jet ski, banana boat, fishing, surf bike, undersea aquarium [6], etc. It certainly needs to be managed and developed so that it can provide a sustainable impact.

The development of marine tourism in Indonesia still faces obstacles such as the absence of price standardisation [7], lack of promotion, inadequate facilities, and infrastructure. Besides this, there are also other problems such as lack of communication and synergy between tourism stakeholders [8]. There are also problems regarding transportation, especially ships. The issue of ship transportation is very crucial for Indonesian marine tourism. It is because if ship transportation is disrupted, then marine tourism that prioritises the potential of small islands will be affected. Although in the research of Nyoman Budiartha (2016) it was shown that maritime transportation had increased and had been dominated by the tourism sector, there were still problems such as the difficulty of finding a reliable vessel provider, guaranteed security, overloaded vessels, etc. [9]. This problem causes conditions not to fit the service criteria for tourism with ship transportation.

This paper will further discuss the issue of ship transportation in Indonesia, especially the problem regarding boat rental. This paper offers ship rental solutions by designing an Android mobile application. The design of this application is made on a mobile app because the use of mobile phones is felt to be very efficient, besides that the internet has also developed data related to travel [10][11]. Also, there are already many sectors that utilise mobile applications to facilitate users better [12]. It is evidenced by research using mobile and internet technology to provide a hybrid package recommendation system for tourism packages [13]. The design of this prototype is based on the User experience (UX) method. By using the user experience method, it is expected to obtain any needs/features that are indeed needed by tourists. It is also because user-generated content is essential in a digital communication environment [14]. In addition to the use of the UX method, it is expected that the application built will meet the factors of the user's emotional needs [15] and the provider's sustainability development, so that the creation of a sustainable and reliable application [16][17].

It is not enough to use UX alone, and a good UI application is also needed so that results can be more impactful [18]. With a good UI application, users will be more satisfied with the product. The UI application can be measured from the level of user convenience to be able to control the use and the level of user understanding of the application [19]. Therefore, a balanced UI and UX will make the interaction between users and the system will be good. In addition, user friendly and effective design will have a good impact on software development [20]. In this paper used design guidelines from Android material design. The goal is that users will be more familiar with standard designs from Android.

The problems that arise from the explanation above are:

- What is the solution to the problem of chartering a ship?

- How to design the application using the UX method?

This paper has the following structure: The next chapter discusses the review literature relating to this subject. Section 3 discusses the research methodology and 
flowchart, which presents the contribution of this paper. Result and analysis are discussed in chapter 4 . In chapter 5 , conclusions and future work will be addressed.

\section{Related Work}

This chapter will discuss research related to the topic of this paper. Relevant research can be seen in table 2 .

Table 2. Related Work

\begin{tabular}{|c|l|l|}
\hline Reference & \multicolumn{1}{|c|}{ Title } & \multicolumn{1}{|c|}{ Result } \\
\hline$[9]$ & $\begin{array}{l}\text { The Development of Marine } \\
\text { Transportation System in Sup- } \\
\text { porting Sustainable Tourism }\end{array}$ & $\begin{array}{l}\text { Finding supporting factors for increasing maritime tourism } \\
\text { include a) support from related institutions, (b) improving } \\
\text { infrastructure, (c) providing sea transportation networks and } \\
\text { services; (d) Support and participation of the local commu- } \\
\text { nity. To get maximum results and profits in tourism. }\end{array}$ \\
\hline$[21]$ & $\begin{array}{l}\text { Key issues for the design and de- } \\
\text { velopment of mobile commerce } \\
\text { services and applications }\end{array}$ & $\begin{array}{l}\text { Suggest a new approach to developing a mobile commerce } \\
\text { application service based on a scheme that divides } \\
\text { applications into a directory and transaction-oriented classes, } \\
\text { identifies mobile user requirements and considers current } \\
\text { technological constraints for cellular and wireless } \\
\text { computing. }\end{array}$ \\
\hline$[22]$ & $\begin{array}{l}\text { Comparing Effectiveness, Effi- } \\
\text { ciency, Ease of Use, Usability } \\
\text { and User Experience When Us- } \\
\text { ing Tablets and Laptops }\end{array}$ & $\begin{array}{l}\text { This study aims to provide a systematic review of the analy- } \\
\text { sis and design of mobile applications, exploring key design } \\
\text { features from the perspective of user experience measured } \\
\text { by the three dimensions of design, namely usability, func- } \\
\text { tion, and aesthetic design. }\end{array}$ \\
\hline
\end{tabular}

Use Based on the problems found in previous research in the field of tourism, that is how to solve the problem of the number of tourist visits and to provide information on tourism. Through cooperation between the government and the private sector in supporting tourism development, infrastructure and network development [9], the impact of mobile technology in e-commerce [21], and mobile application development through user experience design [22]. In this study, we will try to summarise and answer every problem to be able to apply the process of delivering tourism information using a mobile application technology approach where the primary function of the application is as a means of controlling prices to increase the number of visits in the marine tourism sector. And convenience in marine tourism, as well as price control which the government can do. This research is one of the new studies, and no one has ever applied the use of technology in the field of e-commerce to the tourism development process. The mobile application design approach that is carried out will use user experience design. It is used as a design approach because through user experience; it is expected that the mobile application that will be built can be useful according to what is needed by the user himself. 


\section{Proposed Method}

User Experience is a response and the user's view of the use of a system or product [23]. The statement is stated in the ISO 9241-210 standard, which in this statement assumes that the user is the main factor in determining the effectiveness and usefulness of an application or product. User experience assessment factors include the function of the application or product, the performance of the system and the context of use that has an impact on the user's psychological response. The relationship between these factors and mental users can be measured using usability testing. In this paper, we will conduct research using a user experience approach at Marine Tourism.

To measure the relation between prototype design and user, in this study, we will use usability testing. According to Jacob, Nielsen usability is a way to see whether a system is acceptable and good enough to meet all user needs. Some of the uses of usability according to Neilsen are that a system that will be built later can be quickly learned, efficient, easy to remember, has a small error rate, and convenience in use. The series of studies from this paper can be seen in Figure 2.

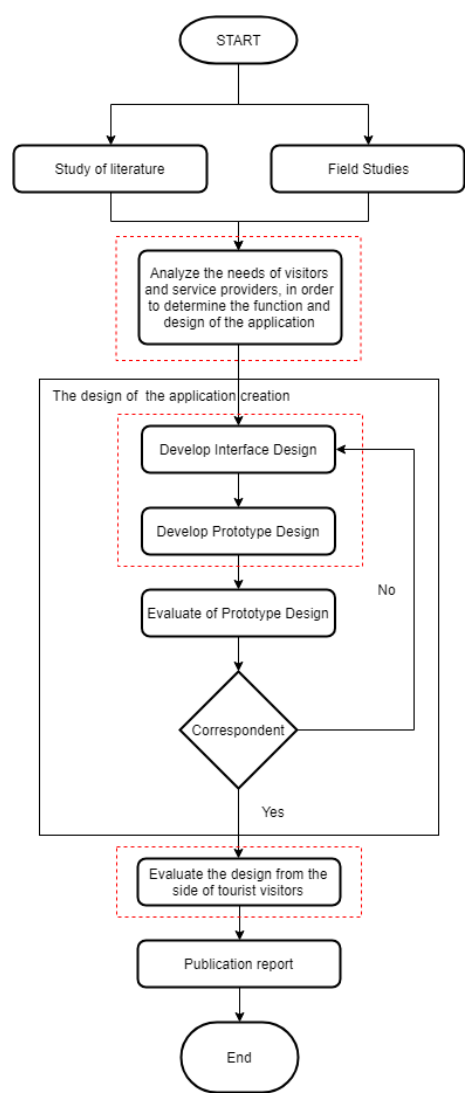

Fig. 2. Research flow chart 
The research flow chart above illustrates the research process of this paper from beginning to end. The research was conducted in several stages. The first stage is data collection. This stage is also often referred to as engineering requirements, which aim to gather user needs [24][25]. At this stage, the data collected came from two sources. The first source is data collected through research documents, such as journals, conference papers, and other official documents. Data collected from this source will be used as a reference in writing this paper. The second data source is data collected through research on the place where the case study was carried out. The data sought from this second source is data about the details of marine tourism features provided, as well as analysing the needs of tourist visitors. From the data, the initial design of this application will be made.

The second stage of this research was to make the initial design of the application design. In this second stage, the application mockup will be made in advance. The content created in this mockup is based on data that has been collected before. After the mockup has been created, the next step is to design an application prototype. This prototype will then be tested for several respondents.

The next step is testing the prototype. The test will involve several respondents that will be asked to use this application prototype. After that, the respondent will be given a Likert scale questionnaire. With this questionnaire's success, data will be taken from the application prototype. From the results obtained, when the data will be processed so that it can be seen whether the response from the user is good or not. If the answer is not good, it will be redesigned again, according to the part that is considered unsatisfactory. Conversely, if the response is good, the final stage will be continued.

\section{$4 \quad$ Result and Discussion}

In this chapter, we will discuss the mockup, sequence diagram process, the final prototype, the results of the prototype test and the results of the questionnaire that has been processed. Following is the mockup and sequence diagram discussion.
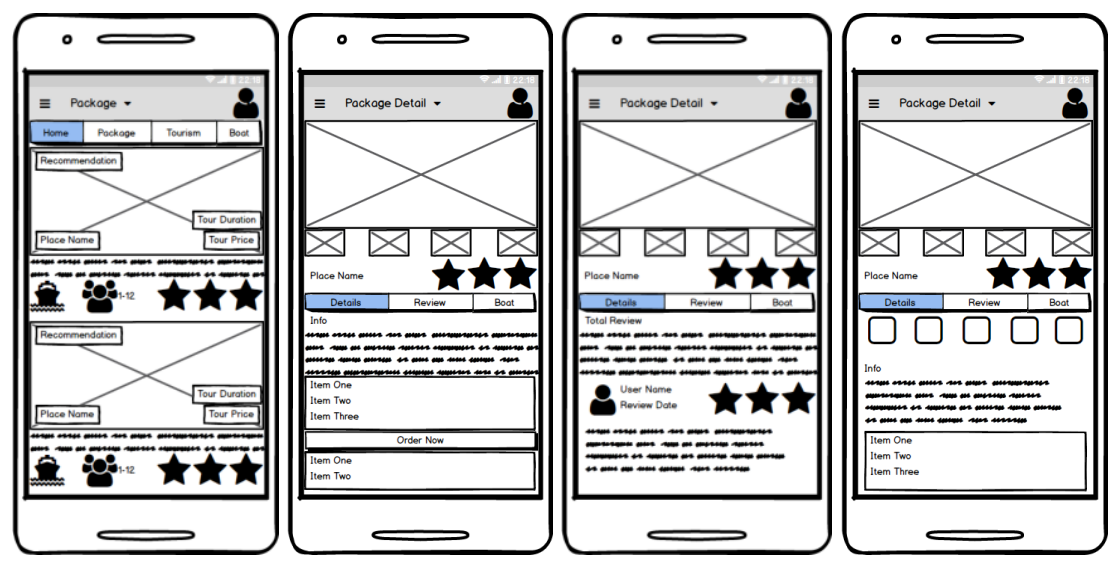

Fig. 3. Package Process Mockup 


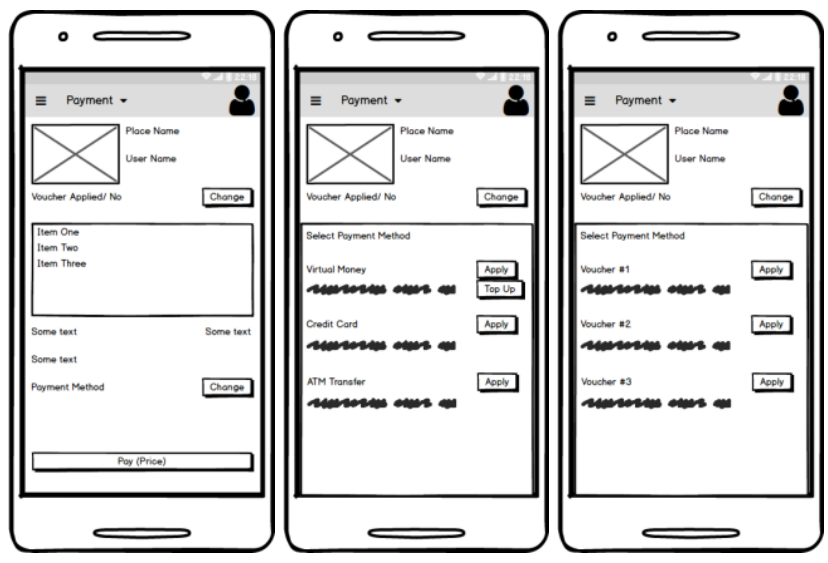

Fig. 4. Payment Process Mockup

Figures 3 and 4 show the display of the package and payment process mockups. The packaging process is the overall design needed when you want to choose a tourism package and its ship. The details of the process will be explained after drawing the sequence diagrams of each process. The following is the sequence diagram process.

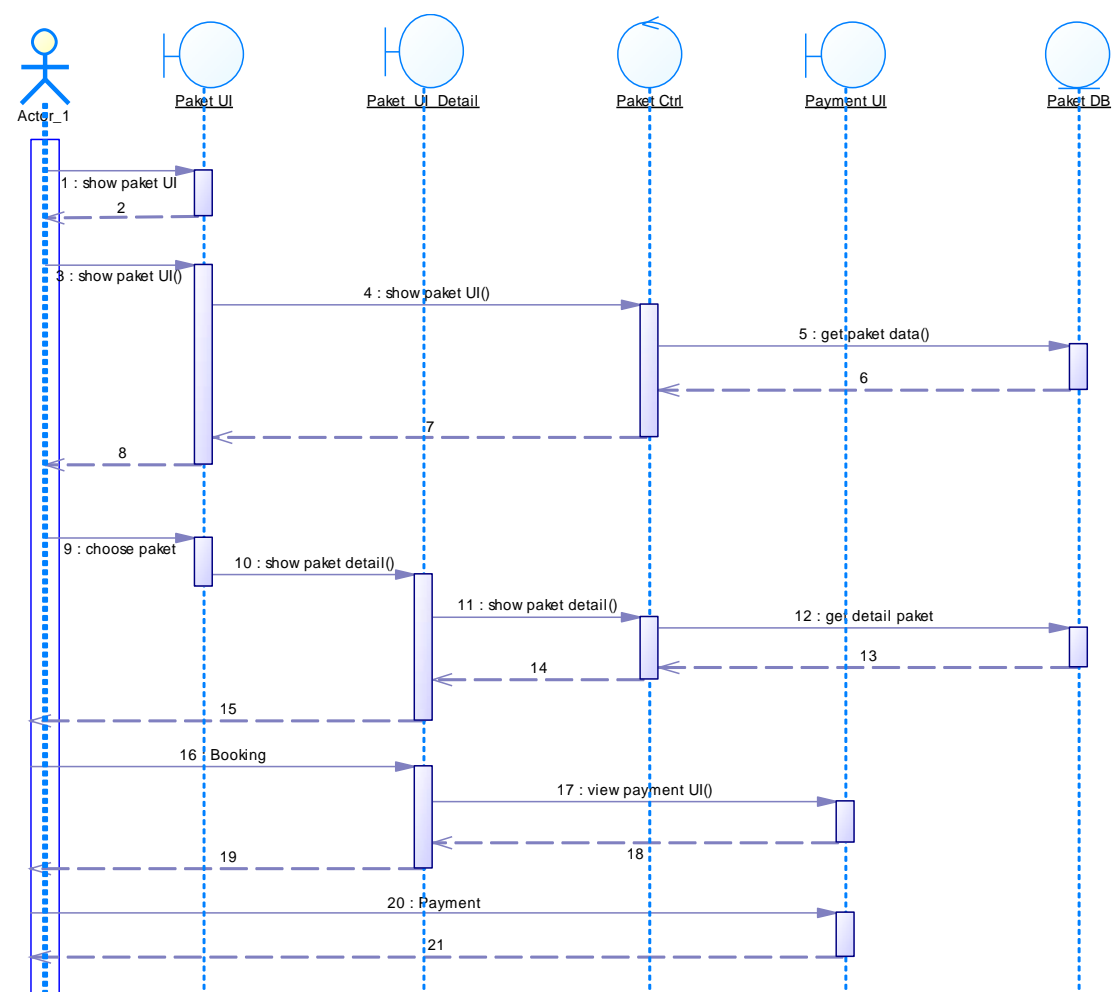

Fig. 5. Sequence diagram package. 
The explanation of the sequence diagram in Figure 5 is as follows. The first actor will open the package page. Then the packet page will retrieve packet data available from the package database. The data will then be sent and displayed to the user. The actor will then choose a tour-package and will be directed to the tour package details page. On this page detail package data will be taken from the database, then displayed. Users who agree with this package and make further bookings will be faced with a payment page. The sequence payment diagram can be seen in Figure 6 .

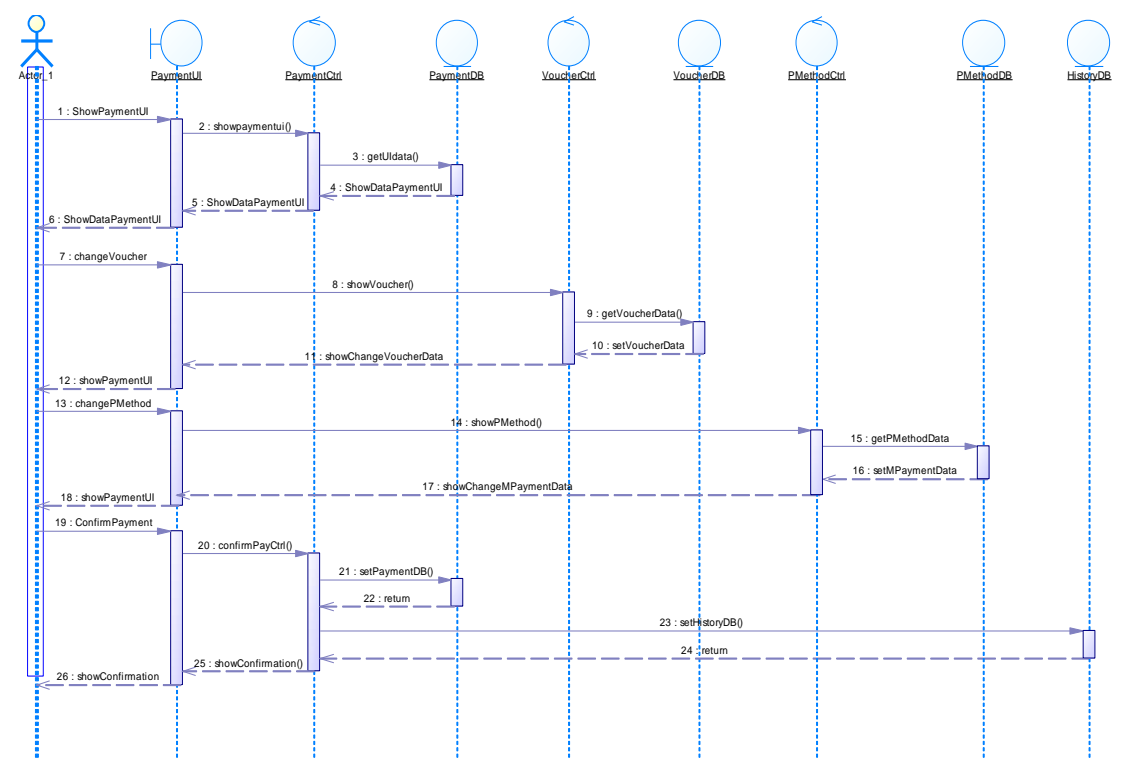

Fig. 6. Sequence diagram payment

In figure 6, you can see sequence diagrams for the payment process. In this process, the actor will be faced with a UI payment. In this interface, the actor can see the payment details that will be paid. Also, actors can choose and change vouchers and payment methods. The actor who will replace the voucher will be faced with a voucher display. In this view, the actor can see various coupons that are owned and can choose the voucher that will be used in the transaction at that time. Actors can also change transaction payment methods. The actor will be faced with the payment method display; then the actor can change the desired payment method. The actor can then make a payment by pressing the payment function button. Payment details will be recapitulated and stored in the payment database and history database. After the payment process is complete, a payment confirmation page will be displayed.

After understanding the process and description of the application mockup to be created, then the mockup test is then performed. this is done so that the design made will be suitable and meet the needs of users. After obtaining the mockup test data, several design improvements were made. The final design can be seen in the following pictures. 


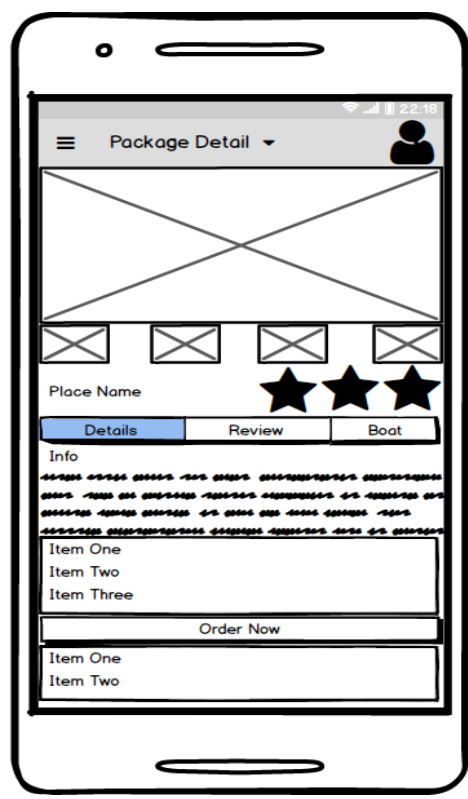

Fig. 7. First detail package mockup
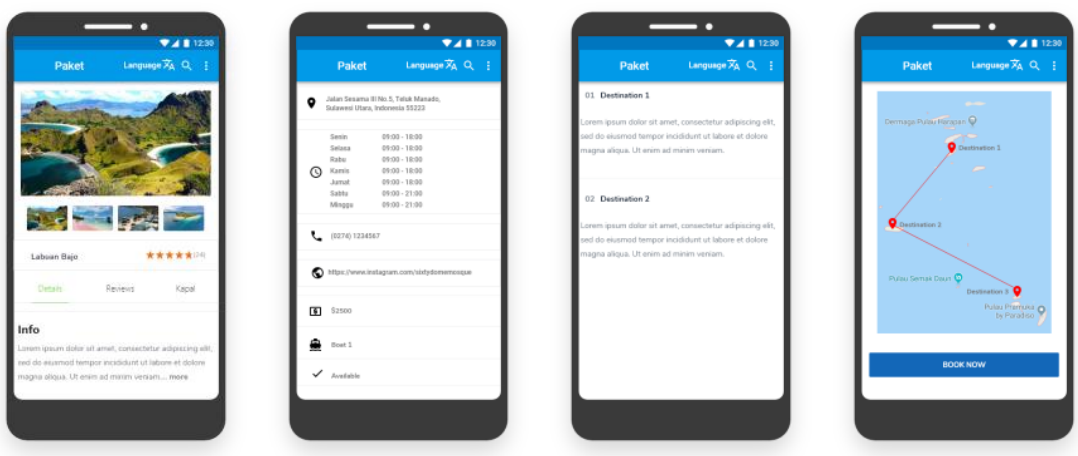

Fig. 8. Final detail package prototype

In figures 7 and 8, the results of the package detail design can be seen. There are some differences between the mockup design and the prototype design. In the final design, the prototype has changed such as the information displayed is complete, the location of the order now button changes, there is a map of tourist routes, and there is a function to switch languages. 


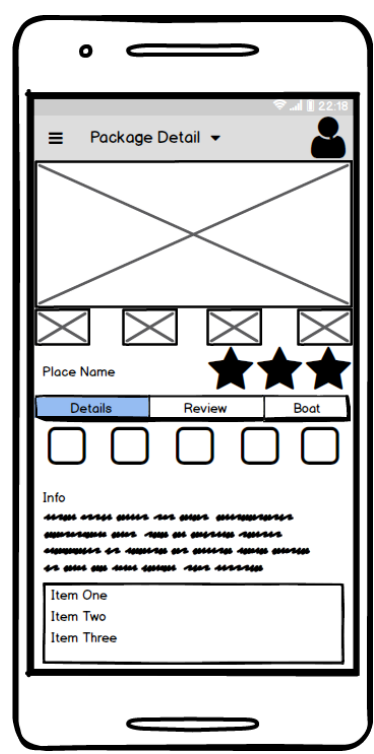

Fig. 9. First boat package detail mockup
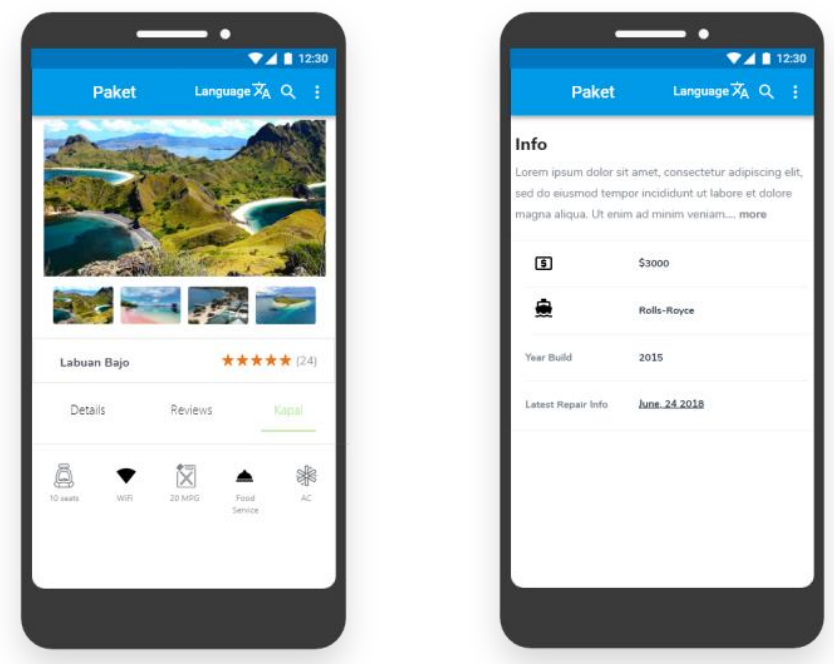

Fig. 10.Final boat package detail prototype

In figures 9 and 10, you can see the results of the boat detail package design. There are some differences between the mockup design and the prototype design. In the final design, there were changes to the prototype, such as the addition of ship info used and the function to switch languages. These changes were made based on the results of the 
questionnaire that had been carried out. Figures 11 and 12 are the overall image prototype of the package detail.
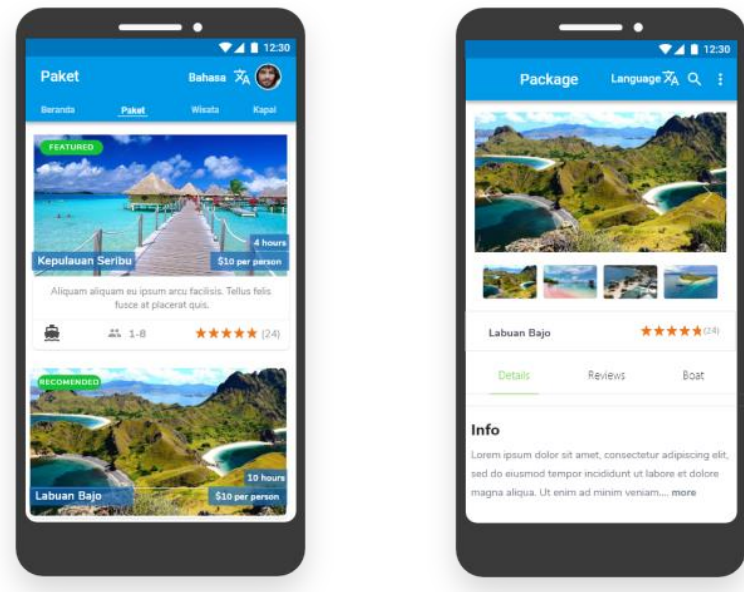

Fig. 11.Prototype Package 1
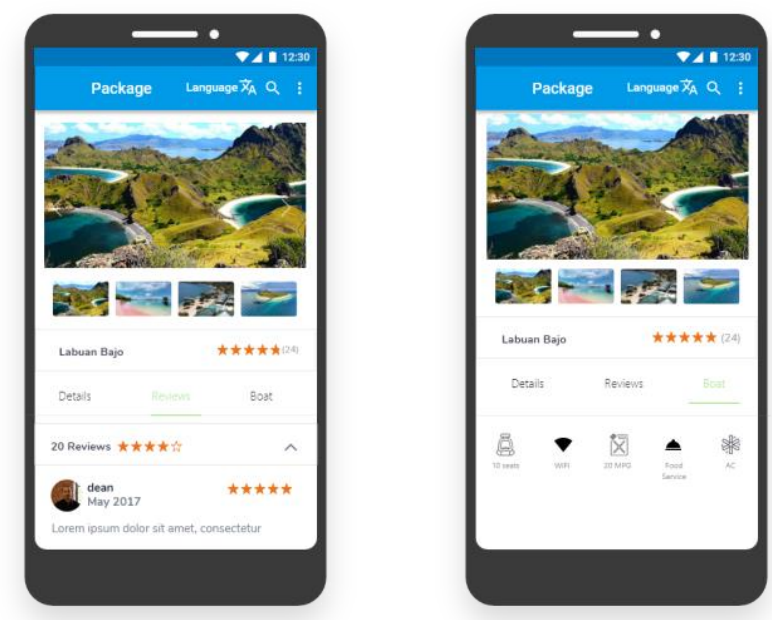

Fig. 12.Prototype Package 2

The series in Figures 11 and 12 are application prototypes when carrying out ship rental and maritime tours through the package page. The process starts from the package page. Users will be faced with various maritime tourism packages accompanied by a 
brief explanation. These short explanations include the duration of tourism, the cost of tourism, the previous rating of users, the capacity of visitors per tourism and a brief description of tourism sites. Users can choose one of the packages provided.

After the user chooses the package, then the user will be faced with the details of the tour package that has been selected. In this tourism detail, tab users can see, tourism details, reviews from previous users, ship details provided for this tourism, and users can book-package packages from this tab. On the tourism details tab, users can see the details of the tour, see the whole tour package, and be able to see the tourist destinations visited. On the Review tab, users can view comments about selected tour packages. On the shipping tab, users can see the specifications and facilities of the ship to be used.

If the user orders this package, then the user will be faced with a payment page. Figures 13 and 14 are a series of payment processes.
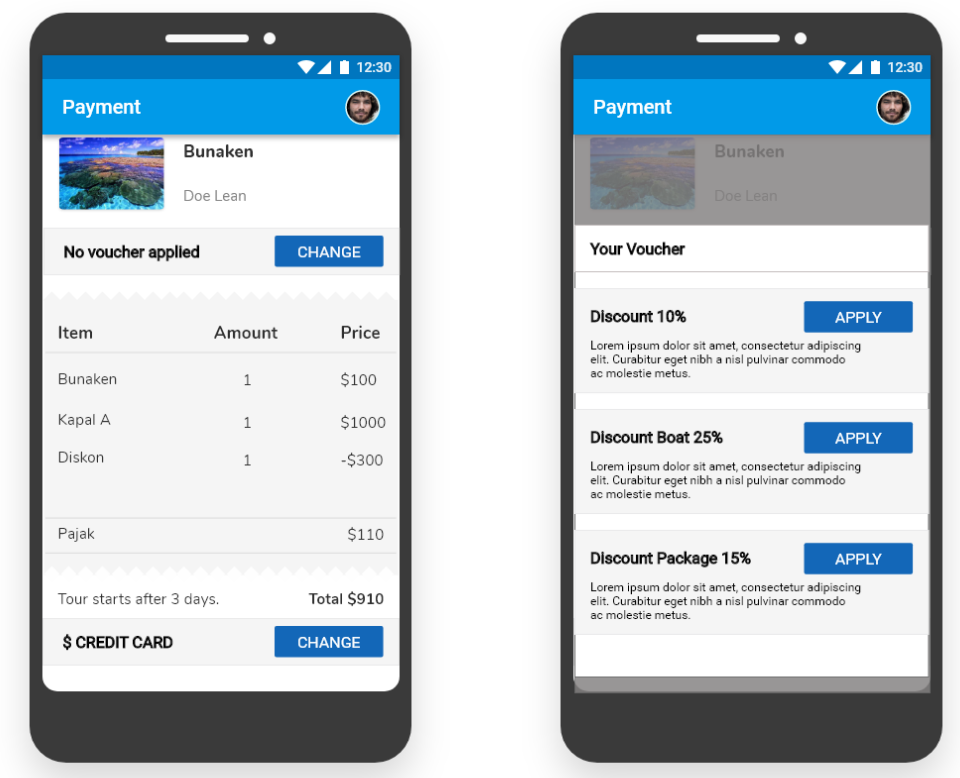

Fig. 13.Prototype Payment 1 


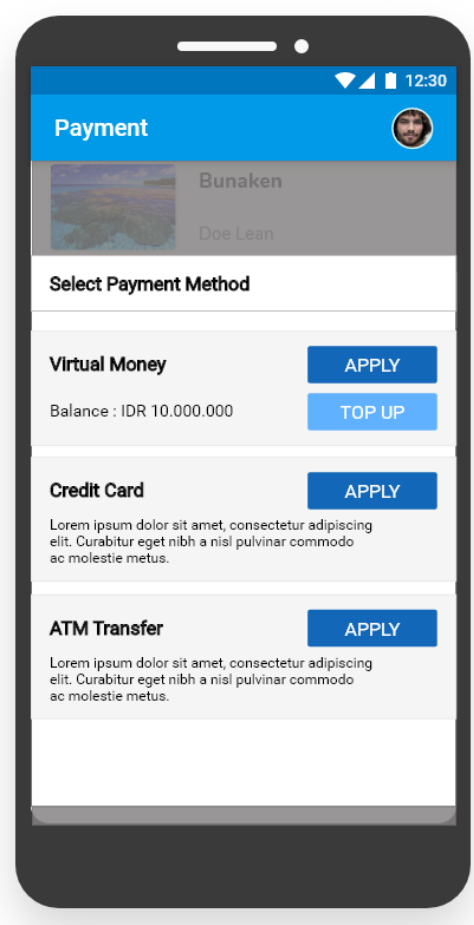

Fig. 14.Prototype Payment 2

In figures 13 and 14, users can see payment details, vouchers, and can choose how payment will be made. Users can choose vouchers in the form of tourist discounts. Users can also select the type of payment to be made. The types of payments provided are various, ranging from virtual money, credit cards, and ATM transfers. The purpose of many of these payment methods is for users to make payments easily. The user can then create a payment by clicking the play button. After that, the payment confirmation will be displayed; this is done so that the user can find out the feedback from the application.

After the prototype is finished, the next step is to do the test again. Just like before the test was carried out using a Likert scale questionnaire. Questions asked about usability, effectiveness, and satisfaction. A summary of the results of the survey can be seen in the following table 3 . 
Table 3. Questionnaire Result

\begin{tabular}{|c|c|c|c|c|c|c|c|c|c|c|c|c|c|}
\hline & Q1 & Q2 & Q3 & Q4 & Q5 & Q6 & Q7 & Q8 & Q9 & Q10 & Total & & \\
\hline SNA & 3 & 1 & 1 & 3 & 2 & 1 & 3 & 2 & 2 & 1 & 19 & $1.3 \%$ & \\
\hline NA & 3 & 6 & 2 & 4 & 3 & 2 & 1 & 1 & 1 & 2 & 25 & $1.7 \%$ & \\
\hline Neutral & 5 & 14 & 16 & 18 & 12 & 17 & 15 & 16 & 7 & 8 & 128 & $9.2 \%$ & \\
\hline $\mathbf{A}$ & 56 & 58 & 55 & 53 & 56 & 57 & 42 & 45 & 52 & 50 & 524 & $37.6 \%$ & \multirow{2}{*}{$87.5 \%$} \\
\hline SA & 72 & 60 & 65 & 61 & 66 & 62 & 78 & 75 & 77 & 78 & 694 & $49.9 \%$ & \\
\hline \begin{tabular}{|l|} 
Res.total \\
\end{tabular} & & & & & & & & & & & 1390 & & \\
\hline
\end{tabular}

From the results of the questionnaire can be seen the percentage of the total response of users who strongly agree (SA) and agree (A) with the prototype design, which amounts to $87.5 \%$. In questions number one and two, ask about how well the functionality and completeness of the information provided. The results obtained showed that most respondents agreed. The result indicates that the application design has been able to provide functionality in line with marine tourism and adequate information regarding marine tourism and boat rental.

\section{Contributions}

This chapter will show the contribution to this research. Contributions to this study are as follows:

- This application design is an application design for lending the first unique island archipelago tourism vessel in Indonesia.

- The design results are made suitable and following the needs of marine tourism in the archipelago.

- The design of this application provides easy access to and precise information.

\section{Conclusion}

Maritime tourism in Indonesia is diverse and spread in various regions of Indonesia. Indonesia's marine tourism is also known to have a positive impact on the economy of citizens. Local governments prioritise marine tourism for 35\% of the entire Indonesian tourism sector. It creates opportunities for marine tourism to develop. Therefore this research focuses on marine tourism, especially tourism that uses ships as part of tourism. That makes boat availability and ways to facilitate boat rental essential. Based on the research and results of the questionnaire that has been done, by applying UX in this study can be known what the user needs applications and application features. Respondents responded strongly agree (approximately 90\%) with the information and functionality required for marine tourism. The final results of this questionnaire showed the average user agreed with the design of this prototype was $87.5 \%$.

Based on the questionnaire data, then for further research, this application design idea can be realised in the form of a real application. Besides, new research can be 
developed to be more useful not only for users and providers but also can be helpful in the economy of the population of tourism providers.

\section{$7 \quad$ References}

[1] K. P. RI, “'Development of Marine Tourism' in Bahasa Indonesia,” Indonesia, 2017.

[2] Z. Hidayah, D. M. Rosyid, and H. D. Armono, "Planning for Sustainable Small Island Management: Case Study of Gili Timur Island East Java Province Indonesia,” Procedia - Soc. Behav. Sci., vol. 227, no. November 2015, pp. 785-790, 2016. https://doi.org/10.10 16/j.sbspro.2016.06.146

[3] D. Biggs, C. C. Hicks, J. E. Cinner, and C. M. Hall, "Marine tourism in the face of global change: The resilience of enterprises to crises in Thailand and Australia," Ocean Coast. Manag., vol. 105, pp. 65-74, 2015. https://doi.org/10.1016/j.ocecoaman.2014.12.019

[4] L. Noviama, H. S. Arifin, and L. Adrianto, "Study Of Snorkeling Marine Tourism Based On Suitability Area And Carrying Capacity In Taman Nasional Kepulauan Seribu National Park , Dki Jakarta," Int. J. Sci. Technol. Res., vol. 7, no. 8, pp. 7-11, 2018.

[5] N. Towner, "How to manage the perfect wave: Surfing tourism management in the Mentawai Islands, Indonesia," Ocean Coast. Manag., vol. 119, pp. 217-226, 2016. https://doi. org/10.1016/j.ocecoaman.2015.10.016

[6] Y. Sulistyadi, F. Eddyono, and B. Hasibuan, "Model of Sustainable Tourism Development Strategy of the Thousand Islands Tourism Area - Jakarta," J. Econ. Manag. Trade, vol. 19, no. 1, pp. 1-17, 2017. https://doi.org/10.9734/jemt/2017/35989

[7] R. Briandana, C. M. Doktoralina, and D. Sukmajati, "Promotion analysis of marine tourism in Indonesia: A case study," Eur. Res. Stud. J., vol. 21, no. 1, pp. 602-613, 2018. https://doi.org/10.35808/ersj/973

[8] J. Damanik, "Lack of Stakeholder Partnerships in Destination Management: Lessons Learned from Labuan Bajo, Eastern Indonesia," Asian J. Tour. Res., vol. 1, no. 2, pp. 173198, 2017. 10.12982/ajtr.2016.0019 https://doi.org/10.12982/ajtr.2016.0019

[9] N. Nyoman Budiartha RM and I. B. P. Adnyana, "The Development of Marine Transportation System in Supporting Sustainable Tourism Case Study: Nusa Penida Island, Bali Indonesia," J. Sustain. Dev., vol. 9, no. 4, p. 89, 2016. https://doi.org/10.553 9/jsd.v9n4p89

[10] Z. Xiang, V. P. Magnini, and D. R. Fesenmaier, "Information technology and consumer behavior in travel and tourism: Insights from travel planning using the internet," J. Retail. Consum. Serv., vol. 22, pp. 244-249, 2015. https://doi.org/10.1016/j.jretcoser.2014.08.005

[11] R. Harrison, D. Flood, and D. Duce, "Usability of mobile applications: literature review and rationale for a new usability model," J. Interact. Sci., vol. 1, no. 1, p. 1, 2013. https://doi.org/10.1186/2194-0827-1-1

[12] A. H. Chohan, H. Mohd Affandi, J. Awad, and A. I. Che-Ani, "A Methodology to Develop a Mobile Application Model to Appraise Housing Design Quality,” Int. J. Interact. Mob. Technol., vol. 11, no. 6, p. 4, 2017. https://doi.org/10.3991/ijim.v11i6.6379

[13] I. M. A. Wirawan and I. W. B. Diarsa, "Mobile-based Recommendation System for the Tour Package Using the Hybrid Method," Int. J. Interact. Mob. Technol., vol. 12, no. 8, p. 64, 2018. https://doi.org/10.3991/ijim.v12i8.9483

[14] C. A. Scolari and J. Fernández-Cavia, "Mobile Applications and Destination Branding in Spain,” Int. J. Interact. Mob. Technol., vol. 8, no. 2, p. 15, 2014. https://doi.org/10.39 91/ijim.v8i2.3575 
[15] A. Dirin, T. Laine, and A. Alamäki, "Managing Emotional Requirements in a ContextAware Mobile Application for Tourists," Int. J. Interact. Mob. Technol., vol. 12, no. 2, p. 177, 2018. https://doi.org/10.3991/ijim.v12i2.7933

[16] C. Manresa-Yee, P. Ponsa, J. Varona, and F. J. Perales, "User experience to improve the usability of a vision-based interface," Interact. Comput., vol. 22, no. 6, pp. 594-605, 2010. https://doi.org/10.1016/j.intcom.2010.06.004

[17] L. Feng and W. Wei, "An empirical study on user experience evaluation and identification of critical UX issues,Sustain" vol. 11, no. 8, 2019. https://doi.org/10.3390/su11082432

[18] A. Hussain, E. O. C. Mkpojiogu, and K. Suleiman, "A usability testing of a mobile print shop booking and design application," J. Adv. Res. Dyn. Control Syst., vol. 10, no. 10 Special Issue, pp. 1359-1365, 2018.

[19] L. Sanny, K. Larasathy, R. Claudia, and B. Widarman, "The Customer Satisfaction of Online Transportation in Indonesia," J. Phys. Conf. Ser., vol. 1175, no. 1, 2019. https:// doi.org/10.1088/1742-6596/1175/1/012236

[20] I. Qasim, F. Azam, M. W. Anwar, H. Tufail, and T. Qasim, "Mobile User Interface Development Techniques: A Systematic Literature Review," 2018 IEEE 9th Annu. Inf. Technol. Electron. Mob. Commun. Conf. IEMCON 2018, no. June 2019, pp. 1029-1034, 2019. https://doi.org/10.1109/iemcon.2018.8614764

[21] A. S. Andreou et al., "Key issues for the design and development of mobile commerce services and applications," Int. J. Mob. Commun., vol. 3, no. 3, p. 303, 2005.10.1504/IJMC. 2005.006586

[22] W. Wetzlinger, A. Auinger, and M. Dörflinger, "Comparing Effectiveness, Efficiency, Ease of Use, Usability and User Experience When Using Tablets and Laptops," 2014, vol. 8517, no. March 2015. 10.1007/978-3-319-07668-3 https://doi.org/10.1007/978-3-319-076683_39

[23] C. Rusu, V. Rusu, S. Roncagliolo, and C. González, "Usability and User Experience,” Int. J. Inf. Technol. Syst. Approach, vol. 8, no. 2, pp. 1-12, 2015. 10.4018/ijitsa.2015070101

[24] C. WaiShiang, A. Shafreena bt Ahmad Puad, P. Chin Hong, and A. Abdul Halin, "AgentOriented Requirement Engineering for Mobile Application Development," Int. J. Interact. Mob. Technol., vol. 11, no. 6, p. 32, 2017. https://doi.org/10.3991/ijim.v11i6.6760

[25] A. Dirin and M. Nieminen, "mLUX: Usability and User Experience Development Framework for M-Learning,” Int. J. Interact. Mob. Technol., vol. 9, no. 3, p. 37, 2015. https://doi.org/10.3991/ijim.v9i3.4446

\section{Authors}

Fedelis Brian Putra Prakasa is a Master of Informatics Engineering Student at Universitas Atma Jaya Yogyakarta, Yogyakarta, Indonesia. He is a Bachelor of Informatics EngineeringStudent at Universitas Atma Jaya Yogyakarta. His research interests are mobile app design, tourism, and gamification.

Melky Radja is a Master of Informatics Engineering Student at Universitas Atma Jaya Yogyakarta, Yogyakarta, Indonesia. He is a Bachelor of Informatics Engineering Student at Universitas Kristen Duta Wacana Yogyakarta. His research interests are mobile app design, tourism, and IoT.

Suyoto is Professor in Universitas Atma Jaya Yogyakarta, Yogyakarta, Indonesia. He has more than nineteen years of teaching experience. He received his Ph.D. in 2000 
Paper-User Experience Based Mobile Application Design for Boat Loaning at Marine Tourism..

from the National University of Malaysia, Malaysia. His research interests are multimedia, computer graphics, visualization, mobile application, and artificial intelligence.

Article submitted 2019-07-09. Resubmitted 2019-12-21. Final acceptance 2019-12-21. Final version published as submitted by the authors. 